\title{
Health Communication During The Pandemic: A Research For Health Care Professionals
}

\author{
Pandemi Sürecinde Sağlık İletişimi: Sağlık Çalışanlarına Yönelik Bir Araştırma
}

\author{
Mehmet Karanfiloğlu, Dr., E-posta: mehmetktr@hotmail.com \\ Murat Sağlam, Dr. Öğr. Üyesi, Karamanoğlu Mehmet Bey Üniversitesi, Uygulamalı Bilimler Yüksekokulu \\ E-posta:murat4081@hotmail.com
}

https://doi.org/10.47998/ikad.889443

Keywords:

Communication

Technologies,

Health Communication, COVID-19,

Pandemic.
Anahtar Kelimeler:

İletişim

Teknolojileri,

Sağlık İletişimi,

COVID-19,

Pandemi.
$\ddot{O} \mathbf{z}$

Sağlık kadar önemli bir konu olan sağlık iletişimi, gelişen ve değişen koşullar karşısında tekrardan incelemek gerekmektedir. Pandemi süreci ile birlikte tüm sektörlerde olduğu gibi sağlık sektörü de derinden etkilenmiş, hatta pandemi ile mücadelede sağlık çalışanları en ön safta yer almışlardır. Bu süreçte iletişim teknolojilerine duyulan ihtiyaç artmış, zaten dijitalleşmekte olan pek çok süreç ivme kazanarak dijital dönüşüme maruz kalmıştır. Bunun da etkisiyle sağlık çalışanları ve hastaların yoğun olarak bu teknolojileri kullanmakta olduğu bir dönemde bulunmaktayız. Pandemi ile birlikte eski alışkanlıklar değişerek yerine dijital becerilerin önemli olduğu yeni alışkanlıklar gelmiştir. Video konferanslar, "uzaktan" ile başlayan yeni etkinlikler gibi pek çok dijital şey hayatlarımıza dahil olmuştur. Dolayısıyla dijitalleşme ve sağlık alanında yaşanan bu gelişmeler konuya yönelik olarak sağlık çalışanların yeni iletişim olanakları ile ilgili detaylıca analiz edilmesini gerektirmiştir. Bu çalışma ile sağlık çalışanları ve iletişim teknolojileri kullanımları ile ilgili nitel bir çalışma yürütülerek derinlikli bilgiler elde edilmeye çalışılmıştır. Yapılan araştırma ve analiz sonucunda ortaya sağlık çalışanlarının teknoloji kullanım nedenleri ve teknoloji algısı ile ilgili dört adet temaya ulaşılmıştır. Temalar doğrultusunda pandemi süreci ile birlikte sağlık iletişiminde, iletişim teknolojilerinin kullanımının arttığını, hem sağlık çalışanlarının hem de hastalarının telefon, tablet gibi cihazları kullarak iletişimsel faaliyetlerini yürüttükleri ve çeşitli yönlerden fayda sağladıkları sonucuna ulaşılmıştır. 


\section{Introduction}

Communication emerges as a constantly needed phenomenon in every part of our lives. The fact that communication is indispensable makes it relevant in every field. Therefore, health communication is known as a field that arose from this understanding.

The importance of health communication is as critical as the place of health in human life. The importance of healthy communication for a healthy society is undeniable. Besides, studies in the ield of health communication associate the subject with technology (Kreps, Neuhauser, Sparks and Labelle, 2020; Reis, Visser and Frankel, 2013). Many new communication technologies have developed on the axis of technological advancements. Firstly computers, then phones, and nowadays the combination of these are smartphones and tablets ... With the use of these devices, it has become possible to obtain many health information quickly, without visiting a hospital or seeing a doctor. Thanks to the applications equipped with artificial intelligence, the health sector has moved to another dimension. On the other hand, the COVID-19 pandemics, which occurred in 2019 and swiftly appeared omnipresent, made these technologies extra indispensable than ever. Individuals and health care professionals who have to stay under quarantine for months contribute to the digital transformation of health communication by using communication technologies. With this research study, this subject will be examined first with the literature search and the research findings will be included.

\section{Digitalization: Health Communication and Communication Technologies}

The computer and the internet, as a result of the competition in the military area, spread not only to the military operations but also to all sectors. Many transactions required for daily and corporate progress are digitized and enhanced, more efficient, and nonspatial. The increasing speed of digital transformation, the socio-economic developments experienced are pushing it to an indispensable position. Technological conversion, which takes place in the first step of digitalization, facilitates the storage, transformation, and display of large volumes of data while ensuring the rapid and reciprocal transmission of data on a typical channel without losing quality (Erdem, 2011: 39-41). Momentarily, digitalization surrounds us with everything from the watches on our wrist to the clothes we wear.

From this viewpoint, the digitalization products, which newer one is produced each day, are increasing. Furthermore, 2.73 out of 7 purchasing processes have been digitized only in 2019 (Gaurois, Roux, Staquet and Perrotin, 2019). Full-awareness and implementation in Turkey have not been accomplished, while the digital transformation movement has been implemented for many countries. However, with the COVID-19 pandemic process, it is possible to see that steps that cannot be underestimated have started to be taken. In a world where all conditions require digitalization, it is critical for companies of all sizes to digitize their processes to survive (Pratis, 2020).

In the first six months of 2020, four-thousand new companies stepped into e-commerce, is said. Despite the 1500 companies digitalized in the first quarter of the 
year, 2500 in the second quarter, after precaution to COVID-19. Accordingly, the number of companies that introduced digital in the first half of this year increased by 50 percent compared to the same period of the previous year, exceeding 4 thousand in total. SMEs played the most significant role in this increase. (Global Tech Magazine, 2020)

In the increasingly digitalized world, the field of health receives its share. These changes are an obligation and subject health care professionals and patients to an arduous test to adapt to the situation. Of course, it is possible to discover different levels due to its structure consisting of contrasting age groups. While it can be seen that some health care professionals adapt to digital facilities quicker, it can be a bit difficult for some employees. Therefore, it is inevitable for health care institutions to consider such differences, especially in the digital transformation phase.

In this context, benefiting from digital opportunities for health communication depends on the increase in digital literacy. Because in the current situation, the interaction intervenes between the following three: Doctor-Patient and Computer (Pearce, Dwan, Arnold, Philips and Trumble, 2009). The more levels, the more benefit it will be possible to create. Yet, it would not even be possible to use such opportunities. How will health institutions respond to these and similar challenges, and what will be the environmental conditions in the new digital environment? Obviate training and practices necessary subjects such as digital literacy pending due to the insufficiency to acknowledge (Shachak, Hadas-Dayagi, Ziv and Reis, 2009). It is expected that digitalization will penetrate numerous areas in health, especially in a period where movements such as industry 4.0 are becoming more widespread. Many things such as computers, mobile phones, smartphone applications, social networks, corporate websites are indispensable in health communication. Thanks to the digital communication channels and health platforms accelerating the communication and information flow in the field of medicine, it has become considerably simple for both health care professionals and patients to access health information in many areas, especially their own health data.

Recently, it is known that doctors and hospitals use social networking sites in conjunction with corporate websites in health communication. It seems that both hospitals and doctors use their pages, notably on platforms such as Instagram, and YouTube where perpetual interaction is reasonable. It is now in an indispensable position to establish and maintain clinical relationships using social networks. According to studies, such social network accounts are resources that will affect the decision-making process of patients (Mazanderani, O’Neill and Powell, 2013).

In addition to these facilities, it is expected that new communication technologies in many dimensions such as patient-doctor, doctor-doctor, doctor-other health care professionals, health institution, and external environment communication will increase more (Frost and Sullivan, 2018). It is expected that the impact of digitalization on health communication will be outstanding in terms of results such as new communication technologies and the provision of a more personalized health service. "The use and scale up of digital health solutions can revolutionize how people worldwide achieve higher standards of health, and access services to promote and protect their health and wellbeing" (WHO, 2021). 


\section{Uses and Gratifications Approaches and Convergence: Pandemic Process and Health Care Workers}

New communication technologies unify digitalization and health communication. Concurrently, it emphasizes that how and in what direction these technologies can be used by health care professionals. Yet, how to use these possibilities is an important question as much as the technological possibilities. In this context, the perspective of the uses and gratifications approach, and how the communication to be established by using these technologies shall be discussed.

The uses and gratifications approach is based on the studies of Paul F. Lazarsfeld and Herta Herzog in 1942-1944. The basis of the approach is grounded on research that focuses on which programs radio listeners prefer to satisfy their needs (Jensen and Rosengren, 2007: 55). The uses and gratifications approach reveals that the audience is not in a passive position within the mass communication influence theories. Instead of classical approaches, this approach does not accept the audience in a position where the data in the mass media are evaluated in line with the media's desires. Nor does the theory view the audience as passive creatures whose behavior is controlled by the media industry (Rodman, 2007: 60). Instead, it argues that the audience makes decisions in advance, sometimes less deliberately (Hermes, 2002: 283), and uses the media in this direction. The approach, in summary, suggests that there is satisfaction, that a user can be mentioned based on this, and that the media-audience relationship can only be understood from this aspect.

The subject of convergence describes the increasing diversification of technologies along with the singularization of these technological possibilities in terms of the medium. Convergence can be seen in many processes as well as in technologies. In short, convergence in technology; is a terminological definition of being able to do the work we do on different devices with an increasingly integrated and single device (Tasdelen, 2011). According to that, studies on convergence and health communication are insufficient (Kreps, vd., 2020; Reis, vd., 2013). Therefore, many problems related to convergence in health communication necessitate being explained.

On the other hand, new types of coronavirus cases, which first appeared in China and spread globally, presently matured a global pandemic. However, compared to other pandemic precursors, news about the pandemic and the pandemic spread at an incredible speed in this process and the process was closely followed by all states from the first day. Though, due to reasons such as transportation facilities, international commercial operations, tourism, etc., the virus spread rapidly and brought quarantine precautions that lasted for months (precaution for COVID-19 nearly lasted for the whole year, 2020). International flights were canceled, curfews were declared, and many people were lost in this process. Unfortunately, health care workers suffered the most with great effort and energy. Health care professionals were at the forefront of the auction, and although many sectors faced a halt, the health sector had to work at a high pace with overtime.

In the context of the convergence and the use and gratifications approach, health care professionals and patients mostly used communication technologies during the pandemic. 
For instance, questions as; what the target audience minds when selecting messages in health communication, which messages generate feedback, and how patients are affected by the messages which are organized for doctor selection...etc. can be discussed in the context of the use and gratifications approach. When considering social networks, defining the problems is crucial, for instance, what are the factors that affect the preferences of individuals will be useful in creating the messages to be edited. In messages transmission, which devices the target audiences use to access information also arises as a problem. As a result of convergence, everything can be handled over devices such as phones and tablets. Therefore, determining what channel the target audience can receive the messages most accurately and whether they have technological literacy knowledge to use multifeatured technologies shall be carefully considered. In this context, our study, conducted in the light of this information above, is included in our research.

\section{Method}

This research aims to investigate the reasons for health care professionals' use of technology and to reveal some results on technology perception. The data provides information about the technology products used by eight health care employees ( 6 females - 2 males) in daily life. Therefore, in the research, in parallel with the development of information and communication technology, it is to reveal the reasons for using technology by health care professionals. In this context, the technology usage perceptions of health care professionals are examined after providing theoretical research results.

Health care professionals' views on their place and importance on physical and mental health conditions, depending on their use of technology, were discussed. This study was conducted by a qualitative research method. Qualitative research; can be defined as a research design in which a qualitative process is followed to present the participants' perspectives, lives, experiences, tendencies, ideas, feelings, attitudes, and habits holistically and realistically in their natural environment (Y1ldırım and Simsek, 2013: 45). The data were collected by the focus group interview method, which is one of the qualitative research methods. The sample group consists of 8 health care professionals working in the Karaman Province in Turkey. The individuals to be interviewed were selected in line with the identified target, and the convenience sampling method was practiced, which is one of the purposive sampling methods. The design of the research is the case study design, one of the qualitative research designs. It is a research design in which the researcher analyzes a situation, often a program, event, action, process, or one or more individuals in depth (Creswell, 2014: 183). The most basic feature of the qualitative case study is the in-depth investigation of one or a few situations. In other words, factors related to a situation (environment, individuals, events, processes, etc.) are investigated with a holistic approach and the focus is on how they affect the relevant situation and how they are affected by the relevant situation (Y1ldirım and Simsek , 2011: 77). The neutral behavior of the participants in the focus group contributes to the validity and reliability of the study (Sahin, 2009: 27). There should be interaction and participation in focus groups. According to Powell, Single and Lloyd (1996), the focus group interview is "a group 
of people selected and brought together by the researcher to express their opinions and discussions about the problem in the research based on their own experiences" (Powell, Single and Lloyd, 1996). According to Morgan (1998, p. 12), the focus group interview is an interaction that occurs within the group about the problem subject to the research (Morgan, 1998). Considering that interaction is essential in focus group interviews, it is unlikely to reach general information. Participants' participation and opinions about their feelings, thoughts, experiences, and attitudes are crucial in such studies. This participation and ideas are reached with open-ended questions. Revealing how health care personnel is affected by information communication technologies on health communication was aimed at via in-depth knowledge by conducting qualitative research.

The data were collected through semi-structured questions created by the researchers. Open-ended questions were asked to the participants, and the responses were analyzed. In the semi-structured interview, the questions are flexible. Habitually, specific data are collected from each participant. There are no predetermined expressions and statements like in questionnaires (Merriam, 2015: 87). While the questions are specified in advance, there can be more to add during the interview to complete the examination profoundly. In other words, the researchers may ask additional questions or not to ask questions when deemed necessary during the interview process (Karasar, 2004: 165).

The data were classified by preserving the original forms of it, descriptive analysis was conducted by making direct quotations from what participants said. In the descriptive analysis, the method of "quoting" is frequently used in order to reflect the feelings and thoughts of the individuals interviewed or observed in a realistic way. The aim is to convey the results obtained in an interpreted and edited form to the reader (Y1ldirım and Simsek , 2013: 256). Content analysis was used as the data were brought together within the framework of certain concepts and themes. The data obtained from these analyzes were arranged in a way that the reader can understand and transformed into a table. The data generated in the study were recorded with a camera and interview notes were taken.

\section{Findings of Research}

The participants were coded as F1, F2, F3, F4, F5, F6, M7, and M8 according to gender.

Table 1. The Theme and Sub-Themes

\begin{tabular}{|l|l|l|}
\hline \multicolumn{2}{|l|}{ Themes } & Sub-themes \\
\hline \multirow{3}{*}{ Theme 1 } & $\begin{array}{l}\text { Getting information and communication, } \\
\text { Access to support at work, } \\
\text { Bereak-time leisure, } \\
\text { Time saving, } \\
\text { Relations. }\end{array}$ & $\begin{array}{l}\text { Access to family and friends support. } \\
\end{array}$ \\
\hline
\end{tabular}




\begin{tabular}{|l|l|l|}
\hline Theme 2 & Recreational Usage. & $\begin{array}{l}\text { Having fun, being happy, and getting pleasure, } \\
\text { Managing stress, anxiety, and low mood, } \\
\text { Activities of interest and increase motivation. }\end{array}$ \\
\hline Theme 3 & Social Media Usage by Age. & $\begin{array}{l}\text { Childhood and elderliness, } \\
\text { Teenage and adulthood. }\end{array}$ \\
\hline Theme 4 & Zeitgeist on Technology Usage. & $\begin{array}{l}\text { Convenience and modernity, } \\
\text { Fast interaction and conversion. }\end{array}$ \\
\hline
\end{tabular}

Four themes emerged with the analysis of the data in the study. These themes are examined in detail and divided under the main two or more when needed with sub-themes (see Table 1). Findings regarding those themes are briefly explained below.

\section{Theme 1: Impact on Family and Business Relations}

Getting information and communication, Access to support at work, Break-time leisure, Time-saving, Access to family and friends support (see Table 1). According to health care professionals, health communication is affected by the conditions of their personal and work lives. Health communication has formed by the interaction of communication elements in business life and social life. Working conditions can cause health communication to progress positively or negatively. Circumstances may affect the lives of health care employees. Conditions such as fatigue, daily routines, and work stress deeply. Compliance or non-compliance in workplaces or conflicts in their daily lives affect the communication of health care professionals. Especially adverse work environment, stress, decreased productivity, motivation, low job satisfaction. Reasons such as may be the cause of communication conflicts in the workplace and daily life.

Besides, there is an interaction between both business and personal lives of employees thanks to communication technologies. In particular, in a lock-down period, during the ongoing COVID-19 pandemic.

I tried not to let my job affect my life. But I could not. I have had a problem in my personal life. My family is not satisfied with the working hours, and I have to spend the night being on duty at work. Therefore, I want to make some changes. However, unfortunately, our job is a little more difficult during this period. You only feel tired. You cannot find the strength and time you need for yourself and your family, especially in combating the COVID-19 pandemic process. In this process, technology and the internet provide comfort by providing the opportunity to meet with our family, allowing us to get away from the hospital environment, albeit for a short time (F1).

Technology is compelling for me. For example, I can easily access any information. I have the opportunity to communicate comfortably with both family-friends and workplace groups. Most importantly, because I live with my family in different cities, technology is vital to contact them. Technology takes up almost all of my life. For example, I shop online, read on internet-based sites, watch foreign TV series/movies, and use technology even when I do sports at home (F3).

There is technology in all areas of our lives. From now on, everyone, regardless of whether they are old or young, can benefit and access what they want instantly. For example, technology for me is the research I do on health every day for my mother, who suffers from Alzheimer's disease (M7).

I am most dabbled in technology recently. Especially telephone and computer technology devices are efficient for me. For example, there are apps I use on my phone. One of them is the menstrual calendar that I use for my menstrual cycle because it is much more difficult to follow without the 
application than the conventional way. As a woman, I would have more difficulty making my plans and would be caught off guard without the a: The application gives a time interval so that I can act according to that time. The application is the correct prediction for the most time so that I live psychologically more comfortably. Thanks to the application, I can act in a more controlled manner. In the course of life, I am more comfortable, more disciplined, and happier. I can say that I use the computer more than the phone. Thanks to applications such as E-Government (E-Devlet [in Turkish]) and E-Pulse (E-Nabiz [in Turkish]), I can easily access my health information, radiology images, and reports from anywhere. Also, I can follow many things on the agenda on the computer (F2).

As it can be understood from the passages, health care professionals use communication technologies and new digital products while working and in their daily lives. In this context, we can say that communication technologies affect health communication in terms of producing more work with time, space, and less effort. In addition to saving time, it is observed that health care professionals also perform daily activities such as communicating with their families and friends. In this process, where they have to work in an isolated state, especially during the pandemic process, they can work without breaking their connection with the outside world thanks to communication technologies. On the other hand, communication technologies are used at the point of making use of leisure time. We see that it is also used for information, communication, and entertainment. According to the theme content, the participants pass this process effortlessly by courtesy of these technologies.

\section{Theme 2: Recreational Usage}

As a result of the analysis, the following sub-themes were created under the theme: Having fun, being happy, and getting pleasure, Managing Stress, Anxiety, and Low Mood, Activities of interest, and increased motivation. When it comes to communication technologies, it is understood that health care professionals see these tools as entertainment devices. The fundamental reason for this is the boredom of long-term isolation remarkably during the pandemic. It might be natural to get fatigued for individuals who are abandoned for an unpredictable time. Therefore, leisure time activities such as watching videos, reading books, watching movies, listening to music with devices such as phones, tablets, or computers may increase in these periods.

On the other hand, this theme and health communication are pertinent to the motivations of health workers. Digital facilities allow health care professionals to be connected with their families or relatives during the pandemic and enable them to catalyze the process and have a pleasant time. Thus, when they return to work, they can work with higher motivation to combat the epidemic.

Well, these technologies are lifesavers for me. I have small children, and I use them to keep my kids busy when I have a lot to do. I open cartoons on the phone or tablet, so they can watch funny videos while I get my work done. Sometimes they watch online course videos and study. Sometimes I also read about child health and healthy nutrition. Besides being educational, I find entertaining programs and videos for my children. I am having fun when they are having fun. These are all possibilities that technology provides for me and gives me comfort (K5).

I can say that I am very dependent on technology because I need to access the information I want instantly. Thanks to these possibilities, we can both be informed and communicate. And it is perfect for having a pleasant time. Whether it is the music I listen to for entertainment, the games I play to distract me when I get bored with work, and the YouTube videos I watch, I make it all thanks to these digital applications. All these things make up my whole life, so my phone has a great place and importance in my life (F4). 
Some of the participants mentioned the effects of communication technologies on their physical and mental health. They state that especially the use of gadgets such as phones and tablets have positive and negative impacts on human health and that this has different effects on communication technologies as a recreational medium. The participant with the code F3 explains it as follows:

People become physically cumbersome due to over usage of mobile phones. Because so many people are staring at their phone-screen for hours. It adds disadvantages to their health in many ways. Still, I think these tools are a means of happiness. A happy person feels good. As a 55-year-old woman, I have a feeling that the worlds are mine (laughs) when I finish the housework and pick up my phone (F4).

Considering the usage of recreational technology is the higher amount of usage than rest of the reasons. Five out of eight participants stated that they used it for recreational purposes rather than obtaining information and research. That statement reveals us to understand that the more entertained they get, the more they use the communication technologies.

While using these tools, I realized that I was affected both physically and psychologically. The best way to relieve boredom. It's fun. Sometimes I forget how time passes while looking at the screen. I find something to laugh at. But I am aware that this situation also affects me physically. I sometimes notice that my custody lines increase, as it is sometimes very tiring to look at the phone and computer screen, but I have not done anything for this yet. I know that both the phone and the computer are hazardous for our health, but I cannot stop using them, which shows that I am addicted. That can sometimes affect me positively and sometimes negatively. It has a negative effect because there are a few influencers that I follow. The more I traverse them, the less I realize my life is doing less well. That drags me spiritually into emptiness. I am losing all my motivation. Every job has a challenge, but the life they live and the things they do always seem easier to me, and I often find myself questioning why I can't do it. I received a traditional education and graduated as a health care worker candidate, but they can reach us on the screen and get astronomical prices, and I probably will never see these numbers in my account monthly during my professional career. On the positive side, I can easily reach the people I love. In bad times, the family may not be enough. Thus, talking to my friends and feeling their love makes me very comfortable. Especially, when I go through a difficult time, and that leaves a positive effect on my life motivation (F1).

From time to time we get together with friends and play computer games. We run competitions. So, we're having fun. Life is hard enough in a pandemic so we relax a little (E7).

\section{Theme 3: Social Media Usage by Age}

Another theme reached as a result of the analysis is Social Media Usage by Age. There are two sub-themes under this theme: Childhood and elderliness, Teenage and adulthood. Participants hereabouts state that social networks are used extensively in health communication, but this differs depending on age. When it comes to the social network, it is seen that the information that comes to mind is mostly focused on Facebook, Twitter, Instagram, and YouTube. However, WhatsApp is not seen as a social network, used more intensely than others. One of the participant states is that as follows:

In my opinion, when I think of Social Networks or Social Media, how-ever you call it, there are mobile phone applications named Facebook, Instagram... etc. We use it a lot. Of course, but we have to. I cannot think of myself not using it. Since we are experiencing the COVID-19 pandemic, it is kind of an obligation. Because we have been aware of everything that relates to our positions. Sometimes, we know some kind of important news over social media a lot before than our managers warn. Thus, I follow the Health Minister's Twitter accounts to see what will happen next. And, I do not think that elder people can use it efficiently. We have some elder workers here, they are about to retire soon but I can see that they cannot adapt themselves to use such kind of technologies. Thus, we use it more I guess (F2). 
Another participant states that:

\begin{abstract}
Of course, young ones can use them more than elder ones. Because we were born in it. No escape. But my grandparents have difficulties when using it. I have lots of accounts. Some of them are fake accounts. But it's a need to have a social media face over these applications. Otherwise, you are kinda like not exist. However, we use some more applications that are not social media. Such as WhatsA: We are groups so that we can communicate more and on time. I spent more time on it to catch what is going on (M7).
\end{abstract}

Lately, everything has already started to change with digitalization. Nevertheless, the transformation has gained momentum since the first day of the pandemic. The most crucial factor is individuals become closer with communication technologies, despite the physical isolation of individuals with social isolation and lockdowns. It is not surprising that social networks are frequently used in this process. However, under the differentiation of technological uses between generations, the participants' experiences coordinate to that idea. Participants stated that social networks are mostly used among younger people. The distinction here is that the group consisting of children and the elderly have not yet succeeded enough competencies in using them, and young people were born in a technological inventions time, and they actively use them so that they can survive more productively.

I had worked at Karaman State Hospital before. My son was younger when he was there. I used this kind of technology more often than he did. I was spying on the babysitter at home on my phone. So that nothing wrong with my son. But now my son has grown. He's more capable of using the phone now than I am. He knows the things I didn't know. Sometimes I even learn the news from him. 'Mama! Did you hear that?', 'The Minister of Health said this', warns me like 'because he said this, he said that'. I get the news from him even before we get it officially. You know, they say, 'little pitchers have long ears'. That's exactly what I am in. But I use social media more effectively than my mother and father. I have accounts on many platforms. So, I have been using social networks for almost ten years. But it has been two or three years for my mother to open a new account. They are also just starting to learn but are not able to do it fully yet (F2).

Although the daily technology usage number of individuals seem to be diminishing on older users, it is naturally the differentiation of usage areas and forms. Now that many habits can change between generations and results can occur due to time differences. It is understandable that while media and internet use may be predominant in teenagers and adults, it can slightly change for elder ones due to the different circumstances of the period in which they were born. The effect of this differentiation in health communication can be observed as follows: Although older employees were more hesitant to use new technologies, the majority of them had to adapt to it in the pandemic. While isolation of elders has emerged during the pandemic, communication technologies competencies had to progress. F3 coded participant expresses this situation as follows:

We are young. We are used to this kind of technology. I mean, I have been using the mobile phone for almost 20 years. But it was getting harder to use it as the age increased. Now they have no other remedies. They are always at home. They have to get used to new phones and follow the news from there. After all, you cannot go out and go to work. They might want to call their son or daughter. Therefore, they learned how to do video calls. They now have social network accounts so that they follow us and receive the news online (F6).

Telephones that provide to talk to family and friends through video calls make these individuals feel in life, thus preventing feeling lonely during the pandemic process. Some participants stated that making video phone calls with their children and grandchildren 
made them extremely happy during this process. Phone usage has increased by the elderly individuals who become lonely by the pandemic, is reported. By these conditions, social media is accessible and widespread for older-aged groups along with younger ones. On the other hand, there are a considerable number of people who follow their work via e-mail and social networks. Therefore, the difference in the amount of social media usage according to the participants' age differentiates the relationship between health communication and communication technologies.

Other information obtained from the interviews is the use of some applications for health communication. Participants expressed that young people prefer phone applications, especially against the elderly who want to benefit from age-related health services conventionally. However, it was stated by the participants that this situation changed gradually during the pandemic. A participant describes this situation as follows:

Previously, older patients used to come, take numbers from the slots and express their complaints in the early hours of the morning from Monday to Sunday. However, the curfews and the threat of the virus, in particular, have notably reduced this situation. They were afraid to come to the hospital unless they were physically urgent. They have already learned that they can control many of their curiosities through their applications. Now they call the doctor through more familiar means and receive such information (F5).

We know that young people have a very high command of social media. Most of the young people who come here make an appointment on the internet. We were seeing that only the old and some young people were making an appointment physically and waiting. Now, this has decreased to a great extent because the pandemic has locked us all into homes. The elders consult over the phone and come after that (M8).

Thanks to applications such as E-Pulse and the Central Physician Appointment System (MHRS: Merkezi Hekim Randevu Sistemi [in Turkish]), health information can be displayed quickly. Appointments can be made with departments in need without applying to hospitals. The "Health Communication Systems" used by every organization, from primary health care institutions to university hospitals, together with tertiary hospitals, provide regular data entry. Moreover, it is easier for both health professionals and patients to access the same information. MHRS was established to reduce the waiting times of the patients, plan the examination period of the physicians, supporting the time management of the physicians, evaluating the examination output times, and preventing patient confusion. Furthermore, it is aimed to increase the efficiency and quality of health services and develop health policies. According to the Ministry of Health data, in 2016, 24/7 appointment service was provided with 3,289 employees, and a total of approximately 105 million people (Saglik-Bakanligi, Faaliyet Raporu 2016, 2017, p. 78), 60.5 million people were appointed in 2017 (Saglik-Bakanligi, Faaliyet Raporu 2017, 2018, p. 153).

In addition to the above-mentioned MHRS, information systems such as E-Pulse, Health-Net, Family Medicine Information System, Hospital Information Management System, Basic Health Statistics Module, and Medicine Tracking System provide systematic information flow in the hospital and reduce error rates in health records.

Family Medicine Information System (AHBS: Aile Hekimligi Bilgi Sistemi [in Turkish]) is a system that records all kinds of services provided by family physicians throughout the country in an integrated manner and transmits them to the data bank under 
the control of the ministry. It starts to follow the individuals from the mother's womb and includes all the health records until death (Alacadagl1, 2019: 11).

The E-Pulse is an application that enables patients and health care professionals to access data obtained in health care institutions whenever and wherever they want via mobile devices. The E-Pulse application contains much information such as hospital visits, test results, laboratory images, prescriptions, drug reports, blood donations, allergies, emergency notes, documents, and disease diagnoses.

Saglik-Net contains all the information about the people who apply to health facilities and receive diagnosis and treatment services and information about the hospitals. Disease burden, physical conditions, and general condition of hospitals and health expenditures are the data that can be accessed from the Health-Net system (Avaner \& Fedai, 2017, p. 5). Referring to this data will give an example of a general way, in 2003, while Turkish population of 66 million; Refer to the health care of about 198 million, while in 2015, Turkish population of 78 million, while health care applications reached 600 million (Saglik-Bakanligi, 2016). Participant M8 stated the health information systems as follows:

I mostly use the drug tracking system and hospital information management system since I work in a hospital and a pharmacy. It provides convenience in tracking drug stock status and expiration dates. Patient-based medication requests reach us instantly, and we prepare medicines on behalf of the patient so that it prevents patient-dose confusion (M8).

\section{Theme 4: Zeitgeist on Technology Usage}

The last theme title has been determined as Zeitgeist on Technology Usage. The sub-themes that make up this theme are Convenience and modernity, Fast interaction, and conversion. Participants state that they make use of technology in many areas of their daily lives. Thanks to the applications, many conveniences change health communication and catches necessities of the time. One of the participants stated is that as follows:

I mostly use my phone applications to get information and send. Social media is for me. I spent most of my time on my profile and others to see what they do, where they go. So that I can see them, at least in this way. I don't think we use it properly, but we do in any way. Also, I use personal health information applications to monitor my health. We already use many technological devices in the hospital. These devices make our job a lot easier and save time, from large equipment such as MR (Magnetic Resonance), CT (Computed Tomography), X-Ray devices to simple tools such as digital sphygmomanometer, digital scale, and glucometer (blood glucose meter). Besides, these devices and information systems used in computers provide healthy information records and regular information flow. Outside of work, I can always stay in touch with my loved ones. I read current news from many different sources and make interpretations by getting information. As multiple perspectives allow me to be more objective and critical, I realize that I have to take other possibilities into account without being bound by one thing, and I often try to apply that to my life (F6).

Another participant reports the following:

Of course, the use of modern technologies is crucial in our job. Because the requirements of the age are changing rapidly. It is necessary to follow and not miss the applications. Now there are apps. Thousands. You download it, and it instantly tells you where is the nearest pharmacy. You tell it hurts here, take this and drink that, and even offer the treatment. These are a great convenience. We are not as fast as young people about using these technologies, but the pandemic forced us to do so. Now we are all experts in new technologies (F3).

For my diabetic father, I investigate the developments in diabetes, what alternatives there will be other than pills instead of needles, how the edema in his body can be reduced by natural methods 
when he takes medicine, how these patients cope with this disease in foreign countries, knowing that the remedies will not be exhausted in the pill. It was never easy to find this information in the past. Time has changed, of course (F5).

The majority of the participants stated that the use of technology in health communication has changed both personal and business lives positively. In addition, some participants mentioned the increasing speed in health communication. Speed and digital transformation seem to have deeply affected both employees and the industry. One participant expressed this situation as follows:

Of course, I use my phone in my business life. When I listen to the work and life stories of our elders, I notice it more clearly. We are at a very good point, especially in hospitals. Everything is easy and fast. We have come to a time when there is no information systems and communication network, where information can be shared from the health care personnel who are circulating files in their hands in a way that all employees can see in seconds. This makes our work extremely easy and saves time. In addition, the quality of health care services and patient satisfaction increases. We can reach researchers on a subject at the national and international level in a short time and keep up-to-date information. I am very pleased with where we are (M8).

Another participant stated the following regarding this theme:

I can say that digital transformation has benefited our industry the most. Because new applications have taken everything to another dimension. Probably, the younger ones do not know how hard it was to get even a little info. But we know deeply. It was taking days and hours sometimes. Now, it just takes only a few minutes and you're done. It's incredible! I use phone applications a lot. Even communication with the patient is easier. There were prescriptions, for example. Now we give a code. The patient just goes to the mash and takes his medicine (M7).

\section{Conclusion}

The issue of health communication emerges as a concern, particularly among the COVID-19 pandemic. Developing technology and changing requirements may vary habits now and then. However, this process has undergone a rapid and compulsory change outside of its state. For this reason, health communication and communication technologies have also moved to a dimension that is used farther intensively.

As a result of the research study, four themes were obtained: Impact on Family and Business Relations, Recreational Usage, Social Media Usage by Age, Zeitgeist on Technology Usage. In the first theme, Impact on Family and Business Relations, it is stated that communication technologies are intensely communicated in the form of communication with family and colleagues, information exchange, supporting during work, interaction at break times, saving time, and getting support from family and friends in stressful occasions. In the second theme, it is explained that these technologies are used for recreational purposes. In this way, getting away from the source of stress, relaxation, motivation, access to interests can be accomplished to make the user pleasant. The third theme states that social media is used in different forms and amounts according to age. It is understood that children and the aged have different usage habits compared to young and adults. Although these groups are similar in some ways, they differ in many cases. The last theme is titled Zeitgeist on Technology Usage. It is generally stated that communication technologies bring many facilities and using modern tools provide some 
advantages. On the other hand, these technologies are reported to be beneficial for rapid interaction and digital transformation.

As can be seen from the themes, the participants mostly have positive thoughts about communication technologies. The main factor here is thought to be the challenges brought about by the current conditions. By all means, every new technology delivers some advantages and disadvantages. Nevertheless, each innovation leads to the emergence of another innovation. Therefore, encountering unusual situations is thought to be likely to occur in such a process.

The study is restricted in the province of Karaman, and the pandemic has not come to an end yet. Accordingly, it is recommended that the argument shall be addressed more comprehensively in further studies, and a similar study shall be repeated in a diminutive intense period after the pandemic. Hence, the results obtained will be able to be more detailed.

\section{References}

Alacadaglı, E. (2019). Bilgi Yönetimi, Dijitalleşme ve Türk Sağlık Sistemi. Journal of Turkish Studies, 14(2), 67-86. doi:http://dx.doi.org/10.7827/TurkishStudies.14918

Avaner, T., \& Fedai, R. (2017). Sağlık Hizmetlerinde Dijitalleşme: Sağlık Yönetiminde Bilgi Sistemlerinin Kullanılması. Süleyman Demirel Üniversitesi İktisadi ve İdari Bilimler Fakültesi Dergisi, 22(Kayfor15 Özel Say1s1), 1533-1542.

Creswell, J. W. (2014). Araştırma Yaklaşımının Seçimi: Nitel, Nicel ve Karma Yöntem Yaklaşımları Araştırma Deseni. (S. Demir, Trans.) Ankara: Eğiten Yayınları.

Erdem, H. A. (2011). Yeni Medya Hizmetleri ve Düzenlemeleri. Uzmanlık Tezi. Ankara: Radyo ve Televizyon Üst Kurulu.

Frost \& Sullivan. (2018, January 12). Frost \& Sullivan's 10 Healthcare Predictions for 2018. Frost \& Sullivan: The Growth Pipeline Company: https://ww2.frost.com/frostperspectives/frost-sullivans-10-healthcare-predictions-2018/ received on 12.01.2021

Gaurois:, Roux, A., Staquet, N., \& Perrotin, E. (2019). Dijital Satınalma Araştırması 2019. https://www.pwc.com.tr/tr/Hizmetlerimiz/danismanlik/tedarik-zinciri-yonetimi/ dijital-satinalma-anketi-2019-2.pdf: PWC-EMEA. received on 12.01.2021

Global-Tech-Magazine. (2020, September 21). KOBI'’lerin dijitalleşme oranı yüzde 50 hizland1. globaltechmagazine.com: https://www.globaltechmagazine.com/2020/09/21/ kobilerin-dijitallesme-orani-yuzde-50-hizlandi/ received on 01.12.2020

Hermes, J. (2002). Active Audiences. In P. C. Adam Briggs, The Media, Second EditioN (: 282-293). Great Britain: Pearson Education Limited.

Jensen, B. K., \& Rosengren, E. K. (2007). Five Traditions in Search of the Audience. In P. G. D McQuail, Communication Theory ve Research (53-70). UK: Sage Publication. 
Karasar, N. (2004). Bilimsel Araştırma Yöntemi. Ankara: Nobel Yayın Dağıtım.

Kreps, G. L., Neuhauser, L., Sparks, L., \& Labelle, S. (2020). Promoting Convergence Between Health Literacy and Health Communication. Studies in Health Technology and Informatics, 269, 526-543. doi:10.3233/shti200060

Mazanderani, F., O’Neill, B., \& Powell, J. (2013). "People power" or “pester power"? YouTube as a forum for the generation of evidence and patient advocacy. Patient Education and Counseling, 93(3), 420-425. doi:https://doi.org/10.1016/j.pec.2013.06.006

Merriam, S. B. (2015). Nitel Araştırma Desen ve Uygulamaları için bir Rehber. (S. Turan, Trans.) Ankara: Nobel Yayınları.

Morgan, D. L. (1998). The Focus Group Guidebook. USA: Sage Publications.

Pearce, C., Dwan, K., Arnold, M., Philips, C., \& Trumble, S. (2009). Doctor, patient and Computer-A Framework for the New Consultation. International Journal of Medicine, 78(1), 32-38. doi:https://doi.org/10.1016/j.ijmedinf.2008.07.002

Pratis. (2020, December 4). Dijital Dönüşüm Nedir? Pratis: Pandemi, Dijitalleşme ve Dijital Satın Alma: https://www.pratis.net/blog/pandemi-dijitallesme-ve-dijital-satinalma/ received on 01.12 .2020

Powell, R. A., Single, H. M., \& Lloyd, K. R. (1996). Focus Groups in Mental Health Research: Enhancing the Validity ofUser and ProviderQuestionnaires. International Journal of Social Psychiatry, 42(3), 193-206. doi:https://doi.org/10.1177/002076409604200303

Reis, S., Visser, A., \& Frankel, R. (2013). Health information and communication technology in healthcare communication: The good, the bad, and the transformative. Patient Education and Counseling, 93, 359-362. doi:10.1016/j.pec.2013.10.007

Rodman, G. (2007). Mass Media in a Changing World. McGraw Hill, USA.

Saglik-Bakanligi. (2016). Sağlık İstatistikleri Yıllığı 2015. Ankara: Türkiye Cumhuriyeti Sağlık Bakanlığı Sağlık Araştırmaları Genel Müdürlüğü.

Saglik-Bakanligi. (2017). Faaliyet Raporu 2016. Ankara: Bizim Dijital Matbaa.

Saglik-Bakanligi. (2018). Faaliyet Raporu 2017. Ankara: Vega Basım Hizmetleri.

Sahin, S. (2009). Fokus Grup Yöntemine Yönelik Reklam Ajansı ve Araştırma Şirketlerinin Tutumu. Yüksek Lisans Tezi. İstanbul: Bahçeşehir Üniversitesi, Sosyal Bilimler Enstitüsü.

Shachak, A., Hadas-Dayagi, M., Ziv, A., \& Reis, S. (2009). Primary Care Physicians' Use of an Electronic Medical Record System: A Cognitive Task Analysis. J Gen Intern Med, 24, 341-348. doi:https://doi.org/10.1007/s11606-008-0892-6

Tasdelen, A. (2011, December 7). Teknolojide Yakınsama Nedir? Retrieved from aykuttasdelen.net: http://aykuttasdelen.net/2011/12/07/teknolojide-yakinsama-nedir/ received on 01.02 .2021 
WHO. (2021). Digital health. World Health Organization: https://www.who.int/ health-topics/digital-health\#tab=tab_1 received on 01.02.2021

Yıldırım, A., \& Simsek, H. (2011). Sosyal Bilimlerde Nitel Araştırma Yöntemleri. Ankara: Seckin Yayıncilık.

Yıldırım, A., \& Simsek, H. (2013). Sosyal Bilimlerde Nitel Araştırma Yöntemleri. Ankara: Seçkin Yayıncılık.

Araştırmacı Katkı Oranı: Ortak bir çalışma olup birinci yazarın (\%60), ikinci yazarın (\%40)

katkısıyla yazılmıştır.

Destekleyen Kurum/Kuruluşlar: Herhangi bir kurum/kuruluştan destek alınmamıştır.

Çıkar Çatışması: Herhangi bir çıkar çatışması bulunmamaktadır. 